\title{
An Investigation of Ethics of Communication in Tourism Translation
}

\author{
Jun Chen ${ }^{1, a}$, Shanshan Luo ${ }^{2, b}$ \\ ${ }^{1}$ College of Humanities and Law, Fujian Agriculture and Forestry University, 15 Shangxiadian Road, \\ Cangshan District, Fuzhou, Fujian, China \\ ${ }^{2}$ School of Foreign Languages, Fuzhou University, Fuzhou, Fujian, China \\ a cjgullit@163.com, ${ }^{\mathrm{b}}$ fjfzlss@163.com
}

Keywords: Ethics of Communication, Tourism Translation, Translation Strategies

\begin{abstract}
This article explores tourism translation from the perspective of translator's ethics of communication. By collecting data of Chinese tourism resources through field surveys and making a comparison with parallel texts in English-speaking countries, it proposes that though both of Chinese and English tourism texts are a hybrid of "informative plus vocative" functions, priority should be placed upon information delivery in Chinese-English tourism translation to cater to target culture's conventions. After a description of the relationship between tourism translation and ethics of communication, some translation strategies including transliteration plus explanation, explicitation and adpation are proposed. It also argues that translator functions as a mediator and communicator in tourism translation and translator's fulfillment of ethics of communication is conducive to improve tourism translation quality, project a good image of Chinese tourist attractions and ultimately promote communication of different cultures.
\end{abstract}

\section{Introduction}

With the proposal of “The Belt and Road Initiative", tourism industry is burgeoning in China. As World Tourism Organization predicts, China will become the largest tourist destination in the world by 2020. Against this backdrop, an increasing number of tourist attractions in China are adapting themselves to international practice of providing bilingual tourism publicity materials in the hope of establishing a positive international image, attracting foreign tourists and facilitating intercultural exchanges and communication.

Tourism translation is a communicative activity to introduce China's splendid culture and tourism resources to a broader international community, and in tourim translation the translator's ethics lies in "communicating the information in source text to target audience and satisfy their expectation" [1]. In other words, the key to success in tourism translation is to grasp the features of tourism texts and choose appropriate translation strategies to render information in an appropriate and acceptable way for target audience. For translators, cultural and linguistic differences and conflicts should be adjusted to conform to translation ethics.

\section{Ethics of Communication in Translation}

Ethics of communication regards translation behavior as a type of intercultural activity to "further intercultural cooperation between parties who are 'Other' to each other" ${ }^{2]}$. "Translation is not only about texts, but also, and significantly, about people in situations where mediation between cultures is needed" ${ }^{33}$. Chesterman also proposes that "an ethical translator is a mediator working to achieve cross-cultural understanding from the perspective of communication" ${ }^{[2]}$.

In other words, the task of translators will not be limited to linguistic transfer. Translators are inevitably invovled in questions of responsibility to others. Among authors, translation initiators and target readers, translators function as a bridge and translation is a process of cross-cultural communication. However, in reality, it is impossible for translators to satisfy different needs ranging from authors to readers at the same time, and the final translation is the result of balance of 
multi-relations and multi-strategies. Therefore, "increased focus on translation ethics can help to guide translators, interpreters and translation scholars towards their 'right' to act responsibly, and to take their visibility and accountability seriously” ${ }^{[4]}$.

\section{Text Typology and Criteria of Tourism Translation}

There is a close relationship between transaltion strategies and text types. For translators, "understanding the genres of written communication in one's field is essential to professional success" ${ }^{[5]}$. In this section, text typology and criteria of tourism translation will be explored.

\subsection{A Comparison of Text Functions between Chinese and English Tourism Texts}

Peter Newmark categorizes texts into three kinds: informative, expressive and vocative texts. Informative text, covering technical reports, newspapers, papers, memos, and minutes of meetings, is to transmit information, opinions, knowledge, and focuses on its content and theme. Expressive text, mainly consisting of literary texts or artistic works such as autobiography, personal letters, novels, poetry, drama, etc., highlights the author of the text and the text itself. Vocative text, including instructions, publicity, propaganda, etc., is to "call upon the readership to act, think or feel, in fact to 'react' in the way intended by the text" "6].

The field-survey data for comparison and analysis consist of Chinese National 5A Tourist Attraction (Sanfang Qixiang, also knowns as Three Lanes \& Seven Alleys), UNESCO World Heritage (Wuyi Mountain) in Fujian and their counterparts in English-speaking countries. The purpose of textual comparison is to "find the defects in English tourism texts" which Chinese scenic spots present to promote tourism resources and services for target audience, and "thus help to improve the composition of tourism texts in English" ${ }^{[7]}$. Through close-reading and analysis of these texts, it is found that some differences exist in different aspects, which are demonstrated by the table below.

Table 1 Differences between Chinese and English tourism texts.

\begin{tabular}{|c|c|c|c|}
\hline & $\begin{array}{c}\text { Language } \\
\text { features }\end{array}$ & Aesthetic standards & \multicolumn{1}{|c|}{ Text functions } \\
\hline $\begin{array}{c}\text { Chinese } \\
\text { tourism texts }\end{array}$ & Flowery & Parataxis & $\begin{array}{l}\text { to attract tourists attention } \\
\text { and to arouse interests }\end{array}$ \\
\hline $\begin{array}{c}\text { English } \\
\text { tourism texts }\end{array}$ & $\begin{array}{c}\text { Concise and } \\
\text { objective }\end{array}$ & Hypotaxis & $\begin{array}{l}\text { to deliver message and offer } \\
\text { information as well as to } \\
\text { arouse interests }\end{array}$ \\
\hline
\end{tabular}

Though both of Chinese and English tourism texts belong to "informative plus vocative" texts aiming to induce readers to respond in a particular way, the former lay more emphasis on "poetic appellative function which appeals to reader's aesthetic sensitivity" " ${ }^{[8]}$ through frequent use of rhetorical devices and exaggerated descriptions, while the latter pay more attention to delivering valid message to tourists by employing concise and objective language. Translators should be aware of the subtle stylistic differences before performing linguistic transformation in order to achieve the ultimate goal of communication in tourism translation.

\subsection{Criteria of Chinese-English Tourism Translation}

As a communicative behavior, tourism translation is essentially the process of seeking the best relevance between Chinese cognitive context and English cognitive context ${ }^{[1]}$. It is translator's responsibility to convey the information in Chinese tourism texts and meanwhile meet the expectations of overseas tourists.

Owing to different structural models and distinct communicative functions of tourism texts between China and the west, word-by-word and sentence-by-sentence translation will only make 
readers puzzled and the intended effect of translation texts unreached in the context ${ }^{[9]}$. Considering that information delivery is the underlying principle in English tourims texts, ethics of communication will be of significance to offer accurate, effective and true information as well as to satisfy the tourists' needs. Therefore, in Chinese-English tourism transaltion, it is of utmost importance for translators to realize the differences in linguistic preferences and "give priority to information transfer to better cater to target culture's conventions” ${ }^{[10]}$

\subsection{Tourism Translation and Ethics of Communication}

Translation ethics, as a code of conduct and assessment criteria of translation, probes into the basic interpersonal norms and their corresponding moral principles. It lays stresses on the interpersonal relationships during the process of translation. Tourism translation is a kind of communicative activity involving language, society, culture and psychology aiming to convey message and wield influence with translator functioning as a communicator. As a kind of communicative activity, tourism translation is an important carrier of tourism resources and culture. The standardization of the activity will help to offer a comprehensive view to Chinese culture and tourism resources as well as to project a positive image for overseas tourists.

For tourism translation, it is necessary for translator to respect the fact and the reality of the original texts to convey the original information accurately and objectively. As the subject of the entrusted, the translator has the responsibility and obligation to complete the commissioned task according to the requirements of the commissioner. For translation text, the translator is obliged to "consider the cultural norms of the target language and meet the expectations of overseas tourists"

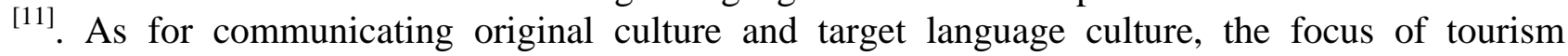
translation is to highlight the differences between cultures as well as promote intercultural communication and cooperation under the principle of fairness and equality. In this system, though the identity of the translator is multiple, his / her central task is to achieve successful cross-cultural communication through linguistic transformation.

\section{Translation Strategies for Chinese-English Tourism Translation in Light of Ethics of Communication}

Ethics of communication implies that the purpose of translation is to promote understanding and communication between different cultures. During the process of tourism translation, some important historical backgrounds and cultural information that embody Chinese traditional characteristics should be explained to foreign tourists to fulfill ethics of communication. Furthermore, different cultures demonstrate disparate preferences for coventional text forms, which play important role in "both text production (because authors have to comply with the conventions if they want to carry out their communicative intentions) and text reception (because receivers must infer the author's intentions from the conventional form of the text)" ${ }^{[8]}$. In the following sections, some translation strategies including transliteration plus explanation, explicitation and adaption will be explored to describe how these strategies contribute to promotion of cultural exchanges and communication in tourism translation.

\subsection{Transliteration plus explanation}

In general, transliteration is used according to the pronunciation of the source language. Transliteration is often applied to translation of proper nouns such as names of people and places. However, from the perspective of communication, it will not be easy for audience to understand the target text produced by transliteration due to the reason that they are unfamiliar with the source culture. In other words, when transliteration and explanation are combined, translation will make sense for target readers.

Example 1: 大王峰又称纱帽岩、天柱峰, 因山形如宦者纱帽, 独具王者威仪而得名。

Suggested translation: Peak Dawang (Peak King) is also known as Rock Gauze Cap or Peak Tianzhu (Heaven Pillar), as its shape is like the gauze cap of ancient Chinese officials, and looks impressive and dignified as a king. 
In Example 1, translator realizes that transliteration alone cannot achieve the desired communicative effect because the meaning can not be fully understood by foreign visitors. Therefore, some explanation is provided on the basis of transliteration to help overseas tourists have a better understanding of the cultural implicature.

Example 2: 文儒坊旧名山阴巷, 以在 “闽山”之北故称。后改为儒林坊。北宋时, 因 “海 滨四先生”之一国子监祭酒郑穆居此, 改名文儒坊。明嘉靖年间, 兵部尚书张经居此, 又称 尚书里。

Wenru Lane, located to the north of Wushan Hill (also known as Minshan Hill), used to be called Shanyin (shade of hill) Alley, and was later renamed Rulin (scholars' circle) Lane. In the Northern Song Dynasty (960-1127), Zheng Mu, Chancellor of the Imperial College and one of the wellknown "Four Coastal Scholars", lived here and the lane was given a new name of Wenru (scholar). During the reign of Emperor Jia Jing of the Ming Dynasty (1368-1644), Minister of War Zhang Jing setteled down here, so the lane was also known as Shangshuli (Minister's Neighborhood).

In Example 2, the italic words in Chinese contain distinctive cultural information, which Chinese can recognize and understand easily. However, if translators do not explain them in the target text, it will make foreign tourists confused. The words “儒林” and “文儒” refer to “scholar” in Chinese, while “明嘉靖年间” and “北宋” refer to ancient Chinese dynasties. “山阴” is literally interpreted as north side of hill, which reveals that it does not have enough sunshine. Nevertheless, the readers cannot grasp the main points if the translation does not provide annotation due to the different cultural backgrounds, language forms and mode of expressions. From the perspective of ethics of communication, translator adopts transliteration plus explanation to enhance the apprehension and achieve successful communication.

\subsection{Explicitation}

Explicitation is "the technique of making explicit in the target text information that is implicit in the source text" "4]. However, it does not mean that the translator can add whatever information as he or she wishes. In effect, translators change the implicit information in the source culture into explicit information with extra explanations for mutual understanding and cross-cultural communication.

Example 3: 董执谊故居……首进厅堂面阔三间，进深七柱……西墙外花厅，为木构三开 间，四坡顶，民国时期建筑……

Former Residence of Dong Zhiyi... The principal hall of the first compound is 3-measurement wide (3 units of bay width, equals $3 * 3$ meters) and 7-measurement deep (7 units of depth between 2 columns, equals $7 * 5$ meters).... The parlour at the western side is a 10 -meter wide wooden structure in Republican style with a hipped roof ...

Example 4: 随着中国航海业的发展, 妈祖信俗得到历朝政府的承认，并册封了各种称号。

With the development of marine industry and the spread of Mazu worship, emperors of ancient China conferred on her the titles of Princess of Heaven, Princess of Numinous Grace and Lady of Numinous Grace.

In Example 3, the Chinese introduction describes the size of the hall without exact Arabic numerals. On the other hand, English version strives for clear message and pays attention to objective facts. If the descriptions are translated directly without transformation of the unit of measurement, it would make foreign tourists puzzled. Therefore, translators add concrete data to facilitate target tourists' understanding and advance cultural exchanges of ancient Chinese architecture. In Example 4, instead of using the gerenal term "Goddess" for the title, translator makes explicit the information as "Princess of Heaven, Princess of Numinous Grace and Lady of Numinous Grace" to retain Chinese cultural flavor and represent the source culture for target tourists.

\subsection{Adaption}

Due to huge differences in aspects of ideology and language structures between Chinese and English, it is inevitable for translators to adapt the source texts to target language conventions in the 
process of tourism translation in order to fulfill the intended function of translation, attract foreign tourists and boost communication.

Example 5: 闽都福州, 钟灵毓秀, 人文鼎盛, 素有 “海滨邹鲁”之美誉。“开一代风气之 先” 的名人灿若繁星，林则徐正是那浩瀚银河中光芒四射的一颗巨星。

Fuzhou is renowned for its stunning scenery and rich cultural inheritance. Among all the distinguished historical figures, Lin Zexu has been hailed as one of the greatest shepherds who endeavored to pave the way for the long overdue modernization of China in the $19^{\text {th }}$ century.

Example 5 is a typical Chinese tourism text with flowery language and four-character structures that most Chinese people are familiar with. Nevertheless, English tourism texts pay attention to precise words, fluency and practical message. Therefore, the first italic expression is adapted to simple sentence so that foreign tourists can understand. The second expression in italics is a typical Chinese metaphor to describe a pioneer with great contributions and strong influence; whereas English-speaking countries are accustomed to adopting the word "shepherd" to represent a person who can lead or guide a group of people. So it is adapted to the familiar phrases "one of the greatest shepherds" to accommodate target audience and spread the intended cultural connotation to tourists. Furthermore, translator also makes explit the abstract meaning of the last sentence by applying necessary historical background to explain Lin Zexu's contribution to the modernization of China.

Example 6: 桃源洞, 环境清静幽雅, 为历代名家隐居的乐土。

Taoyuan Cave, a quiet and tasteful place, has been a fairyland for ancient celebrities to retreat from the temporal world.

In Example 6, the italic Chinese expression means "land of happiness". If the translator does not consider the background of the target readers, the translation will fail to achieve the communicative purpose. Therefore, a functionally equivalent expression "fairyland" is selected to accommodate target audience.

Example 7: 文儒坊乡约碑……碑文曰: “坊墙之内, 不得私行开门, 并奉祀神佛、搭盖遮 蔽、寄顿物件，以防疏虞；三社官衔，禁排列木料等物。光绪辛巳年文儒坊公约。”至今此 碑保存完好，是三坊七巷古代城市里坊社区管理生活的见证。

Words were carved into the tablet to restrict littering or building shrines in the alley. The tablet bears witness to old-time Sanfang Qixiang neighborhood management.

In Example 7, translator adapts to the target reader's preference by simplifying the detailed contents of the tablet in italics. This is due to the consideration that overseas tourists do not have enough cultural background knowledge to understand the quotations or ancient stories in the source text. Consequently, general meaning of the tablet is offered so that target readers can get the information.

\section{Conclusion}

Tourism translation serves as a pivotal platform for foreigners to gain understanding of China's rich culture and fascinating history. This paper probes into the ethics of communication in toursim translation by providing the text typology and criteria of Chinese-English translation of toursim tests. It argues that in tourism translation, priority should be placed on the delivery of information to reproduce a target text conforming to target language norms and conventions. Several translation strategies including transliteration plus explanation, explicitation and adpation are explored accordingly to realize the desired communicative effects of target texts.

There is still room for improvement for this paper. In further studies, more examples will be analyzed to make the conclusion more convincing and objective.

\section{Acknowledgements}

This research is supported by 2016 Fujian Education and Research Project (Grant NO. JAS160166) and FLTRP College English Research Project (Grant NO. 20150016). Special thanks should go to Shanshan Luo, Tingting Xu, Peixun Zhuang, Yiling Shen and Wenjin Zhan, members 
of National Students' Program for Innovation and Entrepreneurship Training, for granting us the permission to use the data of their program.

\section{References}

[1] Zhang, Z. X. (2016) Communicative Norms in Toursim Translation. Shanghai Journal of Translators, 2, 13-16.

[2] Chesterman, A. (2001) Proposal for a Hieronymic Oath. The Translator, 7: 139-154.

[3] Koskinen, K. (2016) Pym, Anthony. 2012. On Translator Ethics. Principles for Mediation between Cultures. Target, 28: 170-177.

[4] Baker, B. \& Saldanha, G. (2009) Routledge Encyclopedia of Translation Studies (Second Edition). Oxford: Routledge, p. 103, 104.

[5] Trosborg, A. (2012) Text typology: register, genre and text type. In Text Typology and Translation, A. Trosborg Eds. Shanghai: Shanghai Foreign Language Education Press, pp. 1-23.

[6] Newmark, P. (1988) A Textbook of Translation. Hertfordshire: Prentice Hall Ubterbatuibak Ltd., p. 41.

[7] Kang, N. (2016) Evaluation in English Tourism Texts on Chinese, British and American Websites: A Corpus-based Comparative Study. Salt Lake City / Miami: American Academic Press, p. 6.

[8] Nord, C. (2001) Translating as a Purposeful Activity: Functionalist Approaches Explained. Shanghai: Shanghai Foreign Language Education Press, p. 43, 53.

[9] Chen, X. W. (2015) A New Coursebook on Pragmatic Translation. Beijing: Economic Science Press, p. 212.

[10] Li, D. C. \& Wang, K. F. (2009) A Model for Comparing Parallel Texts and Its Application in the English Translation of Chinese Tourist Brochures. Chinese Translators Journal, 4: 54-58.

[11] Chen, S. P. (2012) Ethics in Tourist Translation. Chinese Science \& Technology Translators Journal, 3: 45-49. 